\title{
A study of degradation kinetics regarding green peppers' (Capsicum spp.) surface colour
}

\section{Estudio de la cinética de degradación del color superficial del pimentónverde (Capsicum spp)}

\section{Estudo da cinética de degradação da cor da superfície de pimenta verde (Capsicum spp)}

Luis E Ordoñez-Santos' ${ }^{1}$, Luz M Tanganan', Gladien X. Mendez-Molano'

Ingeniero Agroindustrial, PhD, Programa de Ingeniería Agroindustrial, Departamento de Ingeniería, Facultad de Ingeniería y Administración, Universidad Nacional de Colombia.

Email: leordonezs@unal.edu.co

Recibido: Septiembre 12 de 2013.

Aceptado: Mayo 5 de 2014.

\begin{abstract}
Colour is one of the most important factors regarding fruit quality and plays a significant role regarding food products' appearance, processing and acceptability. This attribute quality significantly influences the final decision to purchase food. This work was thus aimed at studying visual colour degradation kinetics regarding green surface colour when blanching green peppers at selected temperatures $\left(60-80^{\circ} \mathrm{C}\right)$. The degradation of green surface colour was measured by -a value or first order kinetics where degradation rate increased with the elevation of temperature. Degradation temperature dependence was suitably modelled by the Arrhenius equation. Activation energy value for green surface colour was $20.16 \mathrm{Kcal} / \mathrm{mol}$. The visual quality of the colour green when green peppers have been thermally treated could probably be objectively determined by using the -a value since this has been reported to be linearly related to green colour and consumer acceptance.
\end{abstract}

Key words: Colour degradation, kinetic parameters, $\mathrm{pH}$, thermal processing.

\section{Resumen}

El color es uno de los factores de calidad más importantes y juega un papel significativo en la apariencia, el procesamiento, y la aceptabilidad de los materiales alimenticios. Este atributo de calidad, influye significativamente en la decisión final de compra de los alimentos. El objetivo de este trabajo es estudiar la cinética de degradación visual del color verde durante el blanqueo de pimentones a temperaturas seleccionadas $\left(60-80{ }^{\circ} \mathrm{C}\right)$. La degradación del color verde superficial medido por el valor -a siguió una cinética de primer orden, en donde la constante de velocidad aumenta al incrementarse la temperatura. La dependencia de la temperatura de degradación fue modelada adecuadamente por la ecuación de Arrhenius. Los valores de energía de activación para el color verde superficial son 20,16 Kcal / mol. La calidad visual del color verde tratado térmicamente en el pimentón probablemente podría ser determinado objetivamente utilizando el valor de $-\mathrm{a}$, ya que se ha informado que es linealmente relacionada tanto con el color verde y la aceptación del consumidor.

Palabras claves: degradación del color, parámetros cinéticos, pH, procesamiento térmico 


\section{Resumo}

A cor de um objecto é um dos factores mais importantes de qualidade e desempem ha um papel significativo na aparência, processamento, e aceitabilidade dos materiais alimentares. Esta qualidade atributo influencia significativamente a decisão final para comprar comida. O objetivo deste trabalho é estudar a cinética de degradação da cor verde visual durante o branqueamento das pimentas em temperaturas selecionadas (60-80 ${ }^{\circ} \mathrm{C}$ ). A degradação da cor verde visuais como medido por um valor-seguido uma cinética de primeira ordem, em que a constante da taxa de aumento com o aumento da temperatura. A dependência da temperatura de degradação foi adequadamente modelada pela equação de Arrhenius. Os valores da energia de ativação para a cor verde visuais eram $20,16 \mathrm{Kcal} / \mathrm{mol}$. A qualidade visual da cor verde tratada termicamente em pimentas poderia provavelmente ser objetivamente determinados utilizando o valor, uma vez que tem sido relatado para ser linearmente relacionado com ambas as cores verde e aceitação do consumidor.

Palavras chave: cinética de parámetros, degradação da cor, pH, tratamento térmico.

\section{Introduction}

Peppers (Capsicum spp) are consumed worldwide, imparting flavor, aroma and color to foods. Besides their sensory importance, peppers play a relevant role on human health since they contain high concentrations of many micronutrient and antioxidant compounds, including ascorbic acid (AA; vitamin C) and carotenoids (Ornelas-Pazet al., 2013). Commercialization and consumption of frozen peppers considerably increased in the last years, due to the demand of the food industry for peppers to be used in pizzas and consumers motivation to eat raw peppers in salads, as a minimally processed vegetable, as part of a healthier diet. Prior to freezing, vegetables are normally blanched in order to inactivate deleterious enzymes, extending in this manner the quality during shelf-life of products (Castro et al., 2011). Heat treatments are common and effective methods of preserving food, but may result in quality loss; color is an indicator of heat-treatment severity and can be used to predict the corresponding quality deterioration resulting from heat exposure. In addition, Xiao et al. (2014) reported the kinetics models of thermal degradation are necessary to design new processes to retain a maximum number of quality factors for safe food production or develop an on-line quality control system for thermal processing for the food industry.

The color of an object is one of the most important quality factors and plays a significant role in appearance, processing, and acceptability of food materials. At the point of sale, the first impact made by a consumer on a food is its visual appearance. It is perceived as part of the total appearance, which is the visual recognition and assessment of the surface and subsurface properties of the food material (Dadali et al., 2007). The color change of food materials during thermal processing takes place because of the reactions oc- curring inside the food material. These reactions can be pigment degradation, especially carotenoids and chlorophyll, and browning reactions such as Maillard condensation of hexoses and amino components and oxidation of ascorbic acid. The final values of color parameters can be used as quality indicators to evaluate deterioration due to thermal processing (Dadali et al., 2007). The color measurements of food materials can be used in an indirect way to determine the color change, since they are simpler and faster than chemical analysis. Dadali et al. (2007) reported color parameters ( $L$, whiteness/darkness; a, redness/greenness; and $b$, yellowness/blueness) have previously proved valuable in describing visual color deterioration and providing useful information for quality control in fruits and vegetables.

Study of the color's change behavior of foods during thermal processing has recently been a subject of interest for various researchers, for example for coriander leaf puree (Ahmed et al., 2004), spinach (Nishaet al. 2004; Dadali et al., 2007), celery leaves (Demirhan and Ozbek, 2011), and aonla (Guptaet al., 2011). Another study addressed by Ornelas-Paz et al. (2013), heat-treated (boiled and grilled) pungent and non-pungent peppers were evaluated for their content of some bioactive compounds and free radical-scavenging activity, but not evaluated the kinetics of thermal degradation of color in peppers. While there are many literature studies on the kinetics of changes in other vegetables, kinetics of visual green color has not been reported for peppers. This information might be useful for people doing product development work with peppers. Therefore, the purpose of this work is to study the kinetics of visual green color degradation during blanching of peppers at selected temperatures $\left(60-80^{\circ} \mathrm{C}\right)$ and also to calculate the activation energies using the exponential expression based on the Arrhenius equation. 


\section{Materials and methods}

\section{Heat treatment of the material}

Green pepper (Capsicum annuum) were procured from local market in the city of Palmira (Valle del Cauca), washed and drained. Thin slices $(37 \mathrm{~mm}$ diameter and $2 \mathrm{~mm}$ thick) peppers were cut perpendicular to the fruit axis. It was assumed that, because of the slenderness of slices, temperature gradients within the samples were minimal. Heat treatments were carried out at different temperatures $\left(60,70\right.$, and $\left.80^{\circ} \mathrm{C}\right)$ for $0-40 \mathrm{~min}$. A water bath was used as a heating device for temperatures up to $100{ }^{\circ} \mathrm{C}$ while.

\section{Color Measurements and physicochemical analyses}

During heat treatment, peppers samples were removed from the water bath at predefined time intervals for color measurements and their color $(\mathrm{L}, \mathrm{a}, \mathrm{b})$ was measured with a Konica Minolta colorimeter (CR-400, Osaka, Japan), using illuminant D65 (8 mm diameter measuring area) and a $2^{\circ}$ observer in a room with controlled light. The instrument was calibrated before the experiments with a white ceramic plate $(Y=89.5$; $x=0.3176 ; y=0.3347)$. Since the peppers samples did not cover the entire surface area, they were scanned at five different locations to determine the average $L$, $a, b$ values during the measurements. The color values were expressed as L, a, and b at any time, respectively. Titratable acidity (g citric acid $100 \mathrm{~g}^{-1}$ pulp), $\mathrm{pH}$ and total soluble solids ( ${ }^{\circ} \mathrm{Brix}$ ) contents were determined using standard methods AOAC (2000). All the analyses were performed in triplicate.

\section{Determination of kinetic parameters}

In order to determine the color change of food materials as a function of heat treatment time, several equations for the application of color change kinetics have been published in the literature (Dadaliet al., 2007; Demirhan and Ozbek 2011; Guptaet al. 2011). Generally, the rate of change of a quality factor $C$ can be represented by

$$
\frac{d C}{d t}=-k C^{n}
$$

Where $(k)$ is the kinetic rate constant, $(C)$ is the concentration of a quality factor at time $t$, and $(n)$ is the order of reaction. For the majority of foods, the timedependence relationships appear to be described by zero-order or first-order kinetic models. Following these evidences, the equation for first order kinetics after integration of equation 1 (Eq. 1) can be written as

$$
\mathrm{C}=\mathrm{C}_{0} \exp ( \pm \mathrm{kt})
$$

The dependence of the degradation rate constant $(\mathrm{k})$ on temperature was quantified by the Arrhenius equation, where

$$
k=A \exp \left(-\frac{E a}{R T}\right) k=A \exp \left(-\frac{E a}{R T}\right)
$$

where $\mathrm{C}_{0^{\prime}}$ measured Hunter color value (a) at time zero (dimensionless); $\mathrm{C}_{t^{\prime}}$ measured Hunter color value (a) or a combination of these at time $\mathrm{t}$; $\mathrm{t}$, heating time $(\mathrm{min})$; $\mathrm{E}_{\mathrm{a}^{\prime}}$ activation energy of the reaction ( $\left.\mathrm{kcal} \mathrm{mol}{ }^{-1}\right) ; \mathrm{R}$, universal gas constant $\left(1.987 \mathrm{Kcal} / \mathrm{mol}{ }^{\circ} \mathrm{K}\right) ; \mathrm{T}$, absolute temperature $(\mathrm{K})$; $\mathrm{A}_{0^{\prime}}$, frequency factor $\left(\mathrm{min}^{-1}\right)$ is a preexponential constant.

Since the major color of green, Hunter-a value (redness/ greenness) was considered as the visual parameter to describe the green color degradation during thermal processing. Therefore, Eq. (2) can be written as

$$
\ln \left(-\mathrm{a} /-\mathrm{a}_{0}\right)=-k \mathrm{t},
$$

Where -a, Hunter -a value at time $\mathrm{t}$ (dimensionless); $-\mathrm{a}_{0^{\prime}}$ Hunter $-\mathrm{a}$ value at time zero (dimensionless); $\mathrm{k}$, rate constant for green color degradation $\left(\min .{ }^{-1}\right)$.

Half-life times for each temperature degrees $\left(t_{1 / 2}\right)$ and $\mathrm{Q}_{10}$ values were determined according to Eqs. (5) and (6)

$$
\begin{aligned}
& Q_{10}=\left[\frac{k_{2}}{k_{1}}\right]^{\left(\frac{10}{\left(T_{2}-T_{1}\right)}\right)} \\
& t_{0.5}=\frac{\ln 2}{k} t_{0.5}=\frac{\ln 2}{k}
\end{aligned}
$$

Where $\mathrm{k}$ is the reaction rate constant at temperature $\mathrm{t}$ $\left(\min ^{-1}\right), \mathrm{T}$ : actual temperature $(\mathrm{C})$.

$\mathrm{D}$ values, the time required to reduce visual green color (-a value) by $90 \%$, and $Z$ values, the temperature required for a $90 \%$ decrease in $\mathrm{D}$ value, were estimated according to Eqs. (7) and (8)

$$
\begin{aligned}
& D=\frac{\ln (10)}{k} \\
& \mathrm{Z}=10 \frac{\ln (10)}{\ln Q_{10}}
\end{aligned}
$$

\section{Statistical Analysis}

The parameters of the kinetic models for Eqs. (2) and (3) were estimated by the linear regression procedure of the MS-Excel 2010 (Microsoft, Inc., USA). 


\section{Results}

The peppers fruit used in the research had a $\mathrm{pH}$ $(5.73 \pm 0.25)$, titratable acidity $(0.10 \pm 0.005 \mathrm{~g}$ citric acid $100 \mathrm{~g}^{-1}$ pulp), soluble solids $(4.70 \pm 0.28)$, and color parameters $\mathrm{L}=38.20 \pm 0.60,-\mathrm{a}=13.18 \pm 1.37$ and $b=13.40 \pm 3.08$. Using linear regression, the degradation data were analyzed using Eq. (4) to determine the overall order and rate constant for the degradation reaction. Accordingly, $\ln \left(-\mathrm{a} /-\mathrm{a}_{0}\right)$ was plotted vs $\mathrm{t}$, from which rate constant, $\mathrm{k}$ was calculated as the slope Fig. 1 shows the representative values for the first order plots for the degradation of greenness (-a value) for peppers at 60,70 and $80{ }^{\circ} \mathrm{C}$, respectively. The rate constants determined from the slopes of the regression lines are presented in Table 1, a correlation coefficient $>0.9$ in all cases confirmed that the degradation of visual green color in peppers indeed follows a first order reaction at all temperatures.

Effect of temperature on the degradation rate constants, is shown in Fig. 2. Results indicated that the dependence of rate constants for -a value on temperature followed the Arrhenius relationship $\left(R^{2}>0.90\right)$. The activation energies for degradation of -a value were $20.16 \mathrm{Kcal} /$ mol (Table 1). High activation energy signifies greater heat sensitivity of visual color degradation during thermal.

In addition to $E_{a}$ values attained from the Arrhenius equation, the $\mathrm{D}, \mathrm{t}_{1 / 2}, \mathrm{Q}_{10}$ and $\mathrm{Z}$ values were calculated (Table 1).

\section{Discussion}

The $\mathrm{pH}$ and titratable acidity obtained in the present study agree with those reported by Méndez et al. (2004) in green materials of Capsicum sp. (5.93 and $0.158 \mathrm{~g}$ citric acid $100 \mathrm{~g}^{-1}$ pulp). By contrast, the surface color $(\mathrm{L}, \mathrm{a}, \mathrm{b})$, differs from those reported by Ornelas-Paz et al. (2013) in green pepper $(L=60, a=-20, b=40)$. The differences in the results compared to other studies may be consequences of the genetic variations, and management factors of pre and post-harvest fruit.

Our results, the rate constants determined, are consistent with those obtained by other studies to evaluate of visual green color in spinach (Nisha et al. 2004) and green peas (Koca et al. 2006) after thermal treatments. Previous studies have reported

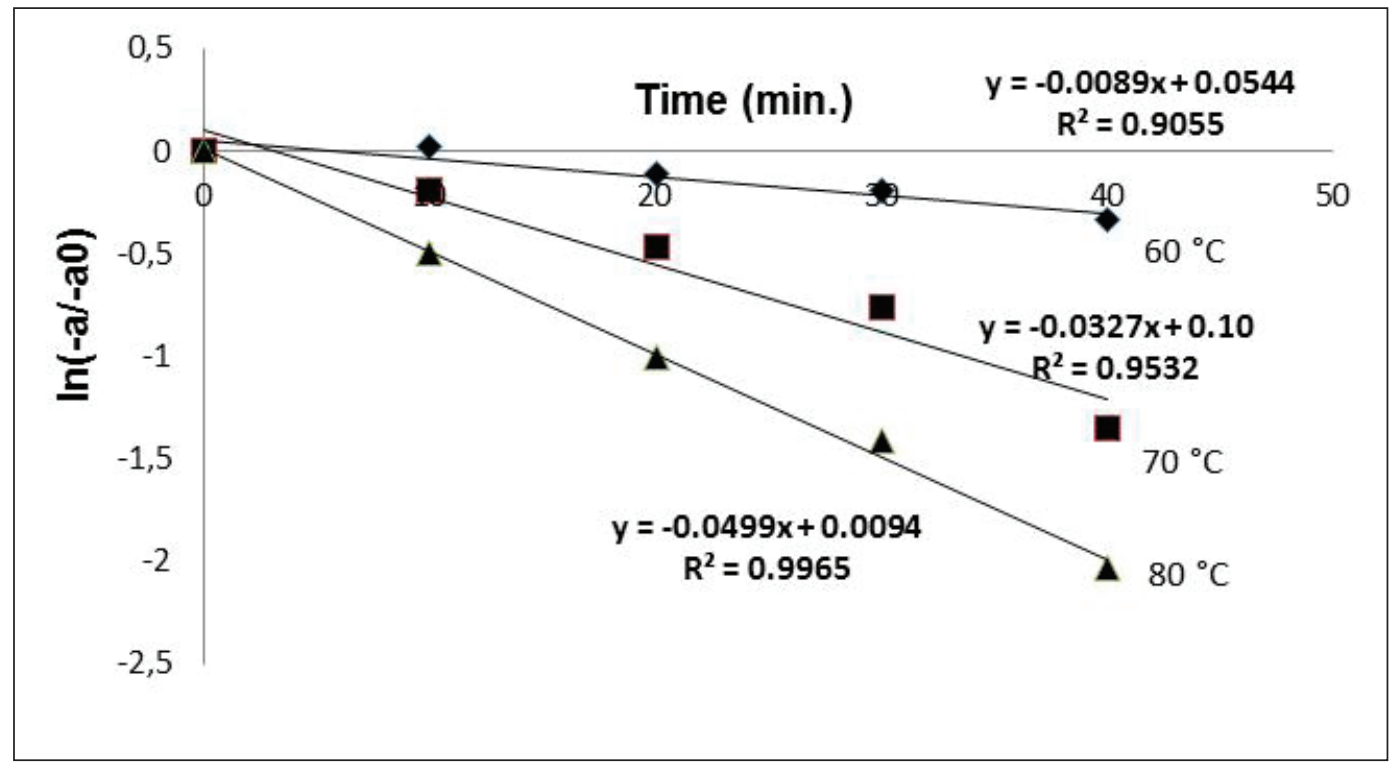

Figure 1. First order plot of color (-a) degradation in peppers at 60,70 and $80^{\circ} \mathrm{C}$.

Table 1. The parameters kinetics of visual green color in peppers

\begin{tabular}{|c|c|c|c|c|c|c|c|}
\hline $\begin{array}{c}\text { Temperature } \\
\left({ }^{\circ} \mathrm{C}\right)\end{array}$ & $k\left(\min ^{-1}\right)$ & $\mathbf{R}^{2}$ & $\mathrm{Ea}(\mathrm{Kcal} / \mathrm{mol})$ & $D(\min )$ & $\mathbf{t}_{0.5}$ & $\begin{array}{c}\mathrm{Q}_{10} \text { value (60- } \\
\left.80^{\circ} \mathrm{C}\right)\end{array}$ & $\mathrm{Z}\left({ }^{\circ} \mathrm{C}\right)$ \\
\hline 60 & 0.0089 & 0.910 & 20.16 & 258.72 & 77.88 & 2.34 & 27.08 \\
\hline 70 & 0.0327 & 0.953 & & 70.42 & 21.20 & & \\
\hline 80 & 0.0499 & 0.996 & & 46.14 & 13.90 & & \\
\hline
\end{tabular}




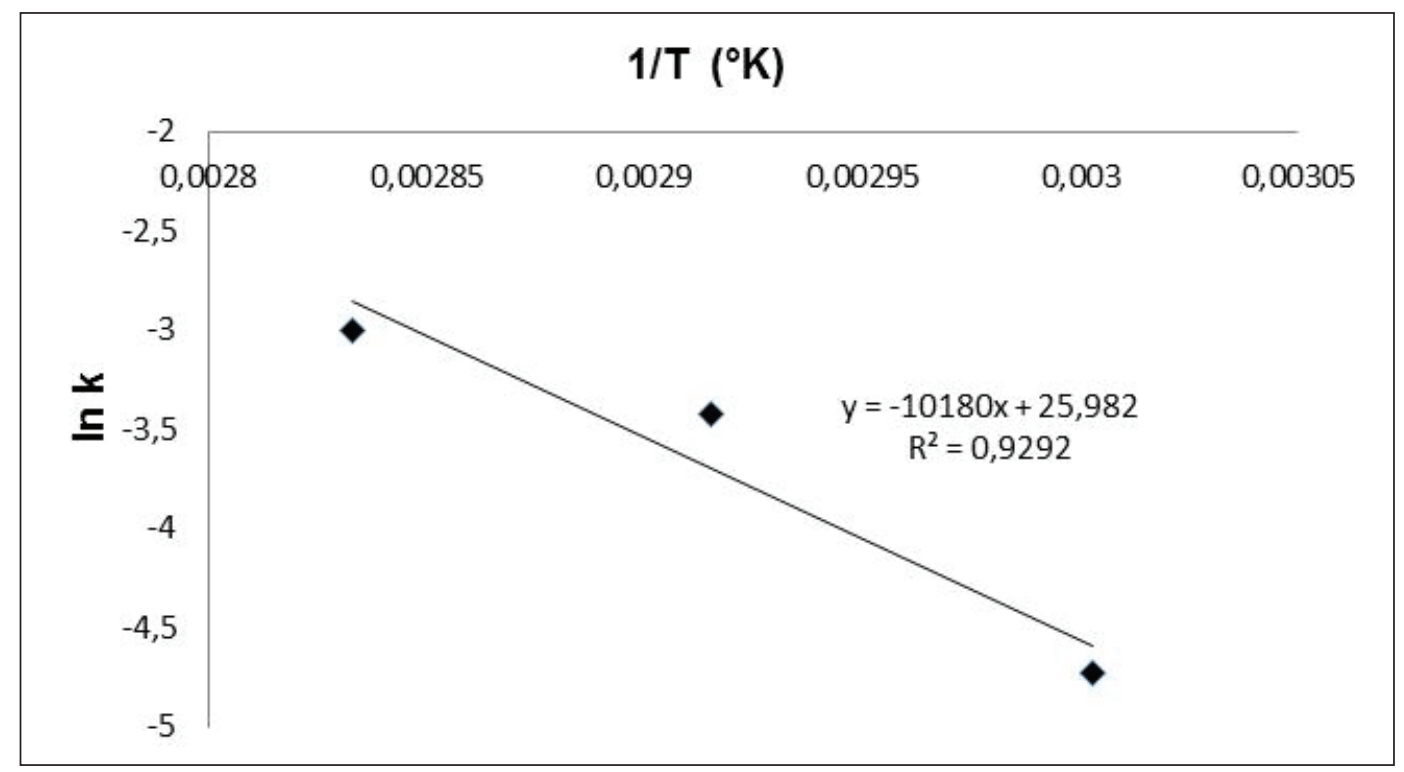

Figure 2. Arrhenius plot for color degradation (-a) in peppers.

wide variation in the activation energies for color degradation of green vegetable. Activation energies for color degradation in peas (Steet and Tong 1996), green chilli (Ahmed et al. 2002), coriander leaf (Ahmed et al. 2004), spinach (Nisha et al. 2004), and green peas (Koca et al. 2006) are reported to be 18.2 (range of 70$90{ }^{\circ} \mathrm{C}$ ), 5.50 (range of $50-90{ }^{\circ} \mathrm{C}$ ), 7.00 (range of 50-110 ${ }^{\circ} \mathrm{C}$ ), 8.95 (range of $50-120^{\circ} \mathrm{C}$ ), and 11.90 (range of 70$\left.100^{\circ} \mathrm{C}\right) \mathrm{Kcal} / \mathrm{mol}$, respectively. These variations may be attributed to the differences in the raw material and the temperature ranges used in these studies. The value of activation energy obtained in the present investigation, evidence that there is a loss of surface color of green pepper samples treated in the temperature range of 60$80^{\circ} \mathrm{C}$, and this reduction of color, it is probably due to the irreversible rupture chlorophyll $\mathrm{a}$ and $\mathrm{b}$ in major derivatives pheophytin a and b (Martínez-Hernández et al., 2013 and Martínez et al., 2013). These results may be useful for designing new thermal processes to preserve surface color or implement quality control systems for the heat treatment as is discussed by Xiao et al. (2014).

\section{Conclusions}

The degradation kinetics of visual green color in peppers followed first order kinetics. The rate constant increased with temperature and the dependence could be described using the Arrhenius equation. The results obtained in our study on the kinetic parameters of thermal degradation kinetics of visual green color provide important information for optimizing the thermal processing of peppers.

\section{References}

Ahmed J, Shivhare US, Debnath S. Colour degradation and rheology of green chilli puree during thermal processing. Int J Food Sci Technol 2002; 37(1): 57-63.

Ahmed JJ, Shivhare US, Singh, P. Colour kinetics and rheology of coriander leaf puree and storage characteristics of the paste. Food Chem, 2004; 84(4): 605-611.

ASSOCIATION OF OFFICIAL ANALYTICAL CHEMISTS-AOAC. Official Methods of analysis. 16thed. Washington, DC: Association of Official Analytical Chemists, 2000.

Castro SM, Saraiva JA, Domingues FMJ, Delgadillo I. Effect of mild pressure treatments and thermal blanching on yellow bell peppers (Capsicum annuum L.). LWT - Food Sci Technol, 2011; 44 (2): 363-369.

Dadali G, Demirhan E, Ozbek B. Color Change Kinetics of Spinach Undergoing Microwave Drying. Dry Technol, 2007; 25(10): 1713-1723.

Demirhan E. OZBEK B. Color Change Kinetics of Celery Leaves Undergoing Microwave Heating. Chem Eng Commun, 2011; 198 (8):1189-1205.

Gupta RK, Kumar P, Sharma A, Patil RT. Color kinetics of aonla shreds with amalgamated blanching during drying. Int J Food Prop, 2011; 14(6):1232-1240.

Hong-Wei X, Chung-Lim L, Da-Wen S, Zhen-Jiang G. Color Change Kinetics of American Ginseng (Panax quinquefolium) Slices During Air Impingement Drying. Dry Technol, 2014; 32: 418-427.

Koca N, Karadeniz F,Burdurlu HS. Effect of pH on chlorophyll degradation and colour loss in blanched green peas. Food Chem, 2006; 100(2): 609-615.

Martínez S, Pérez N, Carballo J, Franco I. Effect of blanching methods and frozen storage on some quality parame- 
ters of turnip greens ("grelos"). LWT. Food Sci Technol, 2013; 51(1): 383-392.

Martínez-Hernández GB, Artés-Hernández F, Gómez PA, Artés F. Quality changes after vacuum-based and conventional indus-trial cooking of kailan-hybrid broccoli throughout retail cold storage. LWT. Food Sci Technol, 2013; 50(2): 707-714.

Méndez MA, Ligarreto GA, Hernández MS, Melgarejo LM. Evaluating growth and determining harvesting index in four types of hot chilli pepper (Capsicum sp.) grown in the Colombian Amazonian region. Agronomía Colombiana, 2004; 22(1): 7-17.
Nisha P, Singhal R.S, Pandit, RS. A study on the degradation kinetics of visual green colourin spinach (Spinaceaoleracea L.) and the effect of salt therein. J Food Eng, 2004; 64(1): 135-142.

Ornelas-Paz JJ, Cira-Chávez LA, Gardea-Béjar AA, Guevara-Arauza JC, Sepúlveda DR, Reyes-Hernández J, Ruiz-Cruz S. Effect of heat treatment on the content of some bioactive compounds and free radical-scavenging activity in pungent and non-pungent peppers. Food Res Int, 2013; 50(2): 519-525.

Steet JA. Tong, $\mathrm{CH}$. Degradation Kinetics of Green Color and Chlorophylls in Peas by Colorimetry and HPLC. J Food Sci, 1996; 61(5): 924-928. 